\title{
Characterisation of penicillinase producing gonococci isolated in Munich, 1981-6
}

\author{
D ABECK,${ }^{*} \dagger$ A P JOHNSON, ${ }^{*}$ H C KORTING $\dagger$
}

From the *Division of Sexually Transmitted Diseases, MRC Clinical Research Centre, Harrow, Middlesex, England, and the †Department of Dermatology, Ludwig-Maximilians Universität, Munich, Federal Republic of Germany

SUMMARY Twenty three penicillinase producing strains of Neisseria gonorrhoeae (PPNG) isolated in Munich from 1981 to 1986 were characterised in terms of their plasmid content, auxotypes, protein I serovars, and sensitivity to antibiotics. Sixteen strains (70\%) harboured a 4.4 megadalton plasmid, with 13 of these strains also containing a 24.4 megadalton plasmid. Seven strains $(30 \%)$ contained a 3.2 megadalton plasmid, with only one of them containing a 24.4 megadalton plasmid. Thirteen strains $(57 \%)$ were prototrophic, eight $(35 \%)$ required proline, one required arginine, and one required proline and arginine for growth. Serovar analysis showed that 16 strains $(70 \%)$ belonged to the protein IB serogroup and comprised four serovars (IB-1, IB-5, IB-7, and IB-8). The seven strains belonging to the IA serogroup also comprised four serovars (IA-2, IA-4, IA-6, and IA-10). Although 18 different categories of plasmid, auxotype, and serovar were found in the 23 PPNG strains, there was a similarity between the auxotypes in terms of the range of serovars they comprised.

Measurement of minimum inhibitory concentrations (MICs) of antibiotics for the strains showed that they were all susceptible in vitro to spectinomycin (MIC $\leqslant 32 \mathrm{mg} / \mathrm{l}$ ), enoxacin (MIC $\leqslant 0.25 \mathrm{mg} / \mathrm{l}$ ), cefotaxime, ciprofloxacin, and ceftriaxone (MICs $\leqslant 0.064 \mathrm{mg} / \mathrm{l}$ ), whereas about half showed some resistance to tetracycline or cefotiam, or both.

Penicillinase producing Neisseria gonorrhoeae (PPNG) strains were first isolated in 1976 in England $^{\prime}$ and the USA, ${ }^{2}$ but have been found subsequently in many countries. ${ }^{3}$ The first PPNG strain isolated in Germany was reported from Munich in $1978 .{ }^{4}$ Epidemiological studies of both PPNG and nonPPNG strains have centred on the characterisation of their plasmid contents, ${ }^{3}$ auxotypes, ${ }^{35}$ and most recently, their protein I serovars. ${ }^{6}$ Using these methods, we characterised 23 strains of PPNG isolated at the Ludwig-Maximilians-Universität, Munich, from 1981 to 1986 and also examined the susceptibility of these strains to eight antibiotics.

\section{Materials and methods}

BACTERIAL STRAINS

Twenty six PPNG strains were isolated at the Department of Dermatology, Ludwig-Maximilians-Univer-

Address for reprints: Dr A P Johnson, Division of Sexually Transmitted Diseases, MRC Clinical Research Centre, Watford Road, Harrow, Middlesex HAl 3UJ

Accepted for publication 13 April 1987 sität, Munich, from 1981 to 1986 . These represented $2 \%$ of the gonococci isolated. Of the 26 PPNG strains originally isolated, 23 were available for study (table 1).

\section{PLASMID ANALYSIS}

Plasmids were extracted from each strain using the method of Birnboim and Doly. ${ }^{7}$ The extracted plasmids were electrophoresed in $0.8 \%$ agarose gels, stained with ethidium bromide, and visualised using long wave ultraviolet light. The plasmid profile of each strain was assessed by comparison with gonococcal strains of known plasmid content, which were provided by Dr A Jephcott, of the Public Health Laboratory, Bristol.

\section{PROTEIN I SEROVAR ASSESSMENT}

The protein I serovar of each strain was assessed by coagglutination using a panel of 12 monoclonal antibodies (Syva) as described by Knapp and colleagues. ${ }^{6}$ Each coagglutination was performed by mixing one drop of a suspension of boiled gonococci with one drop of a suspension of sensitised staphylococci, rotating the mixture for two minutes, then 
Table 1 Incidence of penicillinase producing Neisseria gonorrhoeae (PPNG) strains isolated in Munich 1981-6

\begin{tabular}{lllc}
\hline & $\begin{array}{l}\text { No of } \\
\text { gonoccoci } \\
\text { isolated }\end{array}$ & \multicolumn{2}{l}{ No (\%) of PPNG strains: } \\
\cline { 3 - 4 } Year & 270 & $3(1)$ & 1 \\
\hline 1981 & 266 & $2(1)$ & 1 \\
1982 & 252 & $6(2)$ & 6 \\
1983 & 256 & $4(2)$ & 4 \\
1984 & 234 & $9(4)$ & 9 \\
1985 & 137 & $2(2)$ & 2 \\
1986 & 1415 & $26(2)$ & 23 \\
\hline
\end{tabular}

observing for agglutination under oblique transmitted light.

\section{AUXOTYPE ASSESSMENT}

Organisms of each strain were suspended in phosphate buffered saline at a concentration of about $1 \times 10^{8}$ colony forming units (cfu)/ml. Volumes of $1 \mu$ l of each bacterial suspension were then inoculated on to chemically defined media described by Catlin ${ }^{4}$ using a multipoint inoculator (Denley). The plates were incubated at $37^{\circ} \mathrm{C}$ for 24 hours in an atmosphere of $5 \%$ carbon dioxide in air, after which time the presence or absence of growth was noted. In addition to a complete medium, media lacking either proline, arginine, methionine, lysine, hypoxanthine, or uracil, as well as medium lacking arginine but supplemented with ornithine, were used.

Table 2 Plasmids, auxotypes, and protein I serovars of 23 penicillinase producing Neisseria gonorrhoeae (PPNG) strains isolated in Munich, 1981-6

\begin{tabular}{|c|c|c|c|c|}
\hline $\begin{array}{l}\text { Year } \\
\text { isolated }\end{array}$ & $\begin{array}{l}\text { Strain } \\
\text { No }\end{array}$ & $\begin{array}{l}\text { Plasmids } \\
\text { (megadaltons) }\end{array}$ & Auxotypest & $\begin{array}{l}\text { Protein I } \\
\text { serovars }\end{array}$ \\
\hline $\begin{array}{l}1981 \\
1982\end{array}$ & $\begin{array}{r}1 \\
2 \\
3 \\
4\end{array}$ & $\begin{array}{l}4 \cdot 4,24 \cdot 4 \\
4 \cdot 4,24 \cdot 4 \\
4 \cdot 4,24 \cdot 4 \\
4 \cdot 4,24 \cdot 4\end{array}$ & $\begin{array}{l}\text { Pro }^{-} \\
\text {WT } \\
\text { WT } \\
\text { WT }\end{array}$ & $\begin{array}{l}\text { IB-8 } \\
\text { IB-1 } \\
\text { IB-7 } \\
\text { IB-7 }\end{array}$ \\
\hline 1983 & $\begin{array}{l}\left\{\begin{array}{l}5 \\
6 \\
7 \\
8 \\
9\end{array}\right.\end{array}$ & $\begin{array}{l}4 \cdot 4,24 \cdot 4 \\
4 \cdot 4,24 \cdot 4 \\
4 \cdot 4,24 \cdot 4 \\
4 \cdot 4,24 \cdot 4 \\
3 \cdot 2,24 \cdot 4\end{array}$ & $\begin{array}{l}\text { WT } \\
\text { Pro- } \\
\text { WT } \\
\text { WT } \\
\text { WT }\end{array}$ & $\begin{array}{l}\text { IB-5 } \\
\text { IB-7 } \\
\text { IB-1 } \\
\text { IB-1 } \\
\text { IB-1 }\end{array}$ \\
\hline 1984 & $\begin{array}{l}\left\{\begin{array}{l}10 \\
11 \\
12\end{array}\right. \\
\left\{\begin{array}{l}13 \\
14 \\
15 \\
16\end{array}\right.\end{array}$ & $\begin{array}{l}3 \cdot 2 \\
3 \cdot 2 \\
4 \cdot 4 \\
4 \cdot 4 \\
4 \cdot 4,24 \cdot 4 \\
4 \cdot 4,24 \cdot 4 \\
3 \cdot 2\end{array}$ & $\begin{array}{l}\text { Pro }^{-} \\
\text {WT } \\
\text { WT } \\
\text { Pro }^{-} \\
\text {Pro } \\
\text { WT } \\
\text { Pro }^{-} \text {Arg }^{-}\end{array}$ & $\begin{array}{l}\text { IA-3 } \\
\text { IA-4 } \\
\text { IB-1 } \\
\text { IA-4 } \\
\text { IB-1 } \\
\text { IB-1 } \\
\text { IB-5 }\end{array}$ \\
\hline 1986 & $\begin{array}{l}17 \\
18 \\
19 \\
20 \\
21\end{array}$ & $\begin{array}{l}4 \cdot 4,24 \cdot 4 \\
4 \cdot 4,24 \cdot 4 \\
3 \cdot 2 \\
4 \cdot 4 \\
3 \cdot 2 \\
3 \cdot 2 \\
4 \cdot 4,24 \cdot 4\end{array}$ & $\begin{array}{l}\text { Arg- } \\
\text { WT } \\
\text { WT } \\
\text { Pro- } \\
\text { Pro- } \\
\text { WT } \\
\text { Pro- }\end{array}$ & $\begin{array}{l}\text { IB-8 } \\
\text { IB-8 } \\
\text { IA-2 } \\
\text { IA-6 } \\
\text { IA-2 } \\
\text { IA-10 } \\
\text { IB-1 }\end{array}$ \\
\hline
\end{tabular}

\section{SUSCEPTIBILITY TO ANTIBIOTICS}

The bacterial suspensions used for auxotyping were also inoculated, using a multipoint inoculator, on to media consisting of $1 \%$ GC agar base (Difco) supplemented with $1 \%$ IsoVitalex (BBL) and containing various concentrations of antibiotic. The concentration that completely inhibited the growth of each strain, after incubation for 24 hours as described above, was recorded as the minimum inhibitory concentration (MIC). The antibiotics tested were benzylpenicillin (Glaxo), spectinomycin (Upjohn), tetracycline (Lederle), ciprofloxacin (Bayer UK), enoxacin (Goedecke, FRG), cefotaxime (Roussel), cefotiam (Grünenthal, FRG), and ceftriaxone (Roche, FRG).

\section{Results}

\section{PLASMID CONTENT}

The plasmid content of each of the 23 strains is shown in table 2. All strains contained the 2.6 megadalton cryptic plasmid. Seven strains $(30 \%)$ contained the $3 \cdot 2$ megadalton penicillinase coding plasmid, with one of these strains also harbouring the $\mathbf{2 4 . 4}$ megadalton conjugal plasmid. The other 16 strains $(70 \%)$ had the 4.4 megadalton penicillinase coding plasmid, with 13 of these strains $(57 \%)$ also containing the 24.4 megadalton plasmid. In 1981 to 1983 strains harbouring only the 4.4 megadalton penicillinase coding plasmid were isolated, whereas in each subsequent year strains with both types of penicillinase coding plasmid were isolated.

\section{AUXOTYPE AND SEROVAR}

Each strain was found to belong to one of only four auxotypes, namely wild type (or prototrophic), proline requiring, arginine requiring, or proline and arginine requiring (table 2$)$. Most $(13,57 \%)$ strains were wild

Table 3 Characterisation of 23 penicillinase producing Neisseria gonorrhoeae (PPNG) strains on the basis of their plasmid contents, auxotypes, and protein I serovars

\begin{tabular}{|c|c|c|c|c|}
\hline \multirow{2}{*}{$\begin{array}{l}\text { Plasmids* } \\
\text { (megadaltons) }\end{array}$} & \multicolumn{4}{|c|}{ No (serovar) of strains of auxotypet: } \\
\hline & Wild type & $\mathrm{Pro}^{-}$ & $\mathrm{Arg}^{-}$ & $\mathrm{Pro}^{-} \mathrm{Arg}^{-}$ \\
\hline $3 \cdot 2$ & $\begin{array}{l}1 \text { (IA-2) } \\
1 \text { (IA-4) } \\
1 \text { (IA-10) }\end{array}$ & $\begin{array}{l}1 \text { (IA-2) } \\
1 \text { (IA-3) }\end{array}$ & & $1(\mathrm{IB}-5)$ \\
\hline $\begin{array}{l}3 \cdot 2,24 \cdot 4 \\
4 \cdot 4\end{array}$ & 1 (IB-1) & $1($ IA-4) & & \\
\hline $4 \cdot 4,24 \cdot 4$ & $\begin{array}{l}4(\text { IB-1) } \\
1 \text { (IB-5) } \\
2 \text { (IB-7) } \\
1 \text { (IB-8) }\end{array}$ & $\begin{array}{l}2 \text { (IB-1) } \\
1 \text { (IB-7) } \\
1 \text { (IB-8) }\end{array}$ & 1 (IB-8) & \\
\hline
\end{tabular}

*All strains contained 2.6 megadalton cryptic plasmid.

+Wild type $=$ non-requiring or prototropic; Pro $^{-}=$proline requiring; $\mathrm{Arg}^{-}=$arginine requiring. 
Table 4 Relation between protein I serovars and auxotypes of 23 penicillinase producing Neisseria gonorrhoeae (PPNG) strains isolated in Munich

\begin{tabular}{lllll}
\hline & \multicolumn{4}{l}{ No of strains of auxotype: } \\
\cline { 2 - 5 } Serovars & Wild type & Pro $^{-}$ & Arg $^{-}$ & Pro $^{-}$Arg $^{-}$ \\
\hline IA-2 & 1 & 1 & & \\
IA-3 & 1 & 1 & & \\
IA-4 & 1 & 1 & & \\
IA-6 & 1 & & & \\
IA-10 & 1 & & & \\
IB-1 & 6 & 2 & & \\
IB-5 & 1 & 1 & & \\
IB-7 & 2 & 1 & 1 & \\
IB-8 & 1 & 1 & \\
\hline
\end{tabular}

*Wild type = non-requiring or prototrophic; $\mathrm{Pro}^{-}=$proline requiring; $\mathrm{Arg}^{-}=$arginine requiring

type, eight $(35 \%)$ required proline, one $(4 \%)$ required arginine, and one required proline and arginine. When strains were typed on the basis of their protein I serovar, nine different serovars were detected (table 2). Sixteen strains $(70 \%)$ belonged to the IB serogroup and seven $(30 \%)$ to the IA serogroup. During the years 1981-3 only strains of the IB serogroup were isolated, whereas strains of each serogroup were isolated in subsequent years. The most prevalent serovar was IB1 (found in eight, 35\%), followed by IB-7 and IB-8 (each found in three, 13\%), and IA-2, IA-4, and IB-5 (each found in two, 9\%).

Characterisation of each PPNG strain on the basis of its combined plasmid content, auxotype, and serovar indicated that the 23 strains comprised a heterogeneous group with 18 different combinations of plasmid, auxotype and serovar (table 3). It was, however, interesting to note that there was a similarity between the distribution of serovars in the strains belonging to each auxotype (table 4). Although 16 different combinations of auxotypes and serovars were seen, six of the seven serovars seen in wild type strains were also seen in strains requiring proline or proline and arginine. Similarly, five of the seven serovars detected in proline requiring strains were also detected in the wild type and arginine requiring strains.

Table 5 Minimum inhibitory concentrations (MICs) of seven antibiotics against 23 penicillinase producing Neisseria gonorrhoeae (PPNG) strains

\begin{tabular}{lccc}
\hline & \multicolumn{3}{l}{$M I C(\mathrm{mg} / \mathrm{l})$} \\
\cline { 2 - 4 } Antibiotic & Range & $M I C_{\text {s0 }}$ & $M I C_{90}$ \\
\hline Penicillin & $\geqslant 64-\geqslant 64$ & $\geqslant 64$ & $\geqslant 64$ \\
Tetracycline & $0.032-4$ & 2 & 2 \\
Spectinomycin & $8-32$ & 16 & 32 \\
Cefotiam & $0.002-4$ & 0.5 & 2 \\
Enoxacin & $0.032-0.25$ & 0.125 & 0.125 \\
Cefotaxime & $0.001-0.064$ & 0.008 & 0.032 \\
Ciprofioxacin & $0.004-0.032$ & 0.008 & 0.032 \\
Ceftriaxone & $\leqslant 0.001-0.016$ & 0.004 & 0.016 \\
\hline
\end{tabular}

\section{SENSITIVITY TO ANTIBIOTICS}

The MICs of eight antibiotics against the 23 PPNG strains are shown in table 5: As expected, all the strains were resistant to benzylpenicillin. About half the strains showed some degree of resistance (MICs of $\geqslant 2 \mathrm{mg} / \mathrm{l}$ ) to tetracycline, but none of the strains was resistant (MICs $\leqslant 32 \mathrm{mg} / \mathrm{l}$ ) to spectinomycin. Cefotiam and, to a lesser extent, enoxacin were not as inhibitory as cefotaxime, ceftriaxone, and ciprofloxacin, all of which permitted activity at low concentrations (MICs $\leqslant 0.064 \mathrm{mg} / \mathrm{l}$ ) in vitro.

\section{Discussion}

Public health measures aimed at controlling the spread of gonorrhoea need accurate and widespread surveillance of the disease. Epidemiological studies of gonorrhoea necessarily require that strains of gonococci be differentiated readily. The combined application of the method of auxotyping, serotyping, and plasmid analysis now provides a suitable epidemiological tool. Using this approach, PPNG strains isolated in Munich from 1981 to 1986 could be separated into 18 different classes on the basis of their combined plasmid content, auxotype, and serovar. This indicates that PPNG strains in Munich do not represent the introduction and spread of a single strain, as has been described in some outbreaks. ${ }^{8}$ Instead, the situation seems to resemble that seen in other parts of Germany, where infections with PPNG strains appear to be caused by different strains. ${ }^{9}$ It is not possible to assess whether the variety of PPNG strains in Munich reflects the importation of PPNG strains from other geographical locations or the spread of the penicillinase coding plasmids in the indigenous gonococcal population. The latter is a theoretical possibility because a high proportion of the PPNG strains in Munich carry the $\mathbf{2 4 . 4}$ megadalton conjugal plasmid, which promotes the transfer of penicillinase plasmids between strains.

It was interesting to note that the combinations of auxotypes and serovars found in PPNG strains from Munich differed noticeably from those reported previously for PPNG strains from other parts of Germany. ${ }^{9}$ Of the 20 different combinations of auxotypes and serovars observed in our study and the study reported by Kohl and colleagues, ${ }^{9}$ only four combinations were represented in both studies (table 6). The study by Kohl and colleagues, however, reported on strains isolated during or before $1982,{ }^{9}$ whereas we studied strains isolated from 1981 to 1986 , so the results are not strictly comparable. Indeed, the differences may reflect temporal as well as geographical variation between gonococcal populations. Nevertheless, the data from the two studies provide a good example of how differences between gonococcal 
Table 6 Serovars and auxotypes of 20 penicillinase producing Neisseria gonorrhoeae (PPNG) strains isolated from Munich compared with those from Lubeck and Heidelberg ${ }^{9}$

\begin{tabular}{|c|c|c|c|c|}
\hline \multirow[b]{2}{*}{ Serovar } & \multirow[b]{2}{*}{ Auxotype* } & \multicolumn{3}{|c|}{ Strain in study from: } \\
\hline & & Munich & $\begin{array}{l}\text { Lubeck and } \\
\text { Heidelberg }\end{array}$ & Both studies \\
\hline $\begin{array}{l}\text { IA-1 } \\
\text { IA-2 } \\
\text { IA-2 } \\
\text { IA-3 } \\
\text { IA-4 } \\
\text { IA-4 } \\
\text { IA-6 } \\
\text { IA-10 } \\
\text { IB-1 } \\
\text { IB-1 } \\
\text { IB-3 } \\
\text { IB-4 } \\
\text { IB-5 } \\
\text { IB-5 } \\
\text { IB-5 } \\
\text { IB-7 } \\
\text { IB-7 } \\
\text { IB-8 } \\
\text { IB-8 } \\
\text { IB-8 }\end{array}$ & $\begin{array}{l}\text { WT } \\
\text { WT } \\
\text { Pro }^{-} \\
\text {Pro }^{-} \\
\text {WT } \\
\text { Pro }^{-} \\
\text {Pro }^{-} \\
\text {WT } \\
\text { WT } \\
\text { Pro- } \\
\text { Pro- } \\
\text { Pro- } \\
\text { WT }^{-} \\
\text {Pro- } \\
\text { Pro- Arg- } \\
\text { WT } \\
\text { Pro- } \\
\text { WT }^{-} \\
\text {Pro- } \\
\text { Arg }\end{array}$ & $\begin{array}{l}\text { Absent } \\
\text { Present } \\
\text { Present } \\
\text { Present } \\
\text { Present } \\
\text { Present } \\
\text { Present } \\
\text { Present } \\
\text { Present } \\
\text { Present } \\
\text { Absent } \\
\text { Absent } \\
\text { Present } \\
\text { Absent } \\
\text { Present } \\
\text { Present } \\
\text { Present } \\
\text { Present } \\
\text { Present } \\
\text { Present }\end{array}$ & $\begin{array}{l}\text { Present } \\
\text { Absent } \\
\text { Absent } \\
\text { Absent } \\
\text { Present } \\
\text { Absent } \\
\text { Present } \\
\text { Absent } \\
\text { Absent } \\
\text { Present } \\
\text { Present } \\
\text { Present } \\
\text { Present } \\
\text { Present } \\
\text { Absent } \\
\text { Absent } \\
\text { Absent } \\
\text { Absent } \\
\text { Absent } \\
\text { Absent }\end{array}$ & $\begin{array}{l}\text { Absent } \\
\text { Absent } \\
\text { Absent } \\
\text { Absent } \\
\text { Present } \\
\text { Absent } \\
\text { Present } \\
\text { Absent } \\
\text { Absent } \\
\text { Present } \\
\text { Absent } \\
\text { Absent } \\
\text { Present } \\
\text { Absent } \\
\text { Absent } \\
\text { Absent } \\
\text { Absent } \\
\text { Absent } \\
\text { Absent } \\
\text { Absent }\end{array}$ \\
\hline
\end{tabular}

${ }^{*} \mathrm{WT}=$ wild type, non-requiring, or prototropic; $\mathrm{Pro}^{-}=$proline requiring; $\mathrm{Arg}^{-}=$arginine requiring.

populations can now be detected readily. The further widespread application of the methods of auxotyping, serovar analysis, and plasmid analysis of gonococcal strains offers the chance of greatly increasing our understanding of the epidemiology of gonorrhoea.

Regarding the measurement of MICs, the inocula used here contained about $10^{8} \mathrm{cfu} / \mathrm{ml}$, which is more than is commonly used in other laboratories. Thus the MICs obtained may not be strictly comparable with those obtained by other workers, and may be expected to be slightly higher. Nevertheless, it is still evident that the PPNG strains isolated in Munich are susceptible to several antibiotics including spectinomycin, enoxacin, cefotaxime, ciprofloxacin, and ceftriaxone.
We thank Dr U Neubert, Department of Dermatology, Ludwig-Maximilians-Universität, München, for placing the isolates at our disposal. The suspension of sensitised staphylococi used in the assessments of the protein-I serovars were kindly prepared and provided by Dr C Ison, St Mary's Hospital Medical School, London, who is the United Kingdom distributor for Syva monoclonal antibodies used in typing gonococci. We also thank $\mathrm{Dr}$ Ison for her help and advice on auxotyping, and $\mathrm{Dr} \mathrm{A}$ Jephcott and his colleagues at the Public Health Laboratory, Bristol, for helpful advice on plasmid analysis. We also thank Bayer UK and Roussel for providing antibiotics. DA was supported by a scholarship of the Deutsche Forschungsgermeinschaft.

\section{References}

1 Phillips I. $\beta$-lactamase producing, penicillin-resistant gonococcus. Lancet 1976;ii:565-7.

2 Ashford WA, Golash RG, Hemming VG. Penicillinase-producing Neisseria gonorrhoeae. Lancet 1976;ii:657-8.

3 Perine PL, Thornsberry C, Schalla W, et al. Evidence for two distinct types of penicillinase-producing Neisseria gonorrhoeae. Lancet 1977;ii:993-5.

4 Neubert U, Ruckdeschel G. Isolierung Penicillinase-bildender gonokokken in München. Münchener Medizinische Wochenschrift 1978;120:1063-4.

5 Catlin BW. Nutritional profiles for Neisseria gonorrhoeae, Neisseria meningitidis and Neisseria lactamica in chemically defined media and the use of growth requirements for gonococcal typing. J Infect Dis 1973;128:178-94.

6 Knapp JS, Tam MR, Nowinski RC, Holmes KK, Sandström EG. Serological classification of Neisseria gonorrhoeae with the use of monoclonal antibodies to gonococcal outer membrane protein I. J Infect Dis 1984;150:44-8.

7 Birnboim HC, Doly JA. A rapid alkaline extraction procedure for screening recombinant plasmid DNA. Nucleic Acids Res 1979;7:1513-23.

8 Handsfield HH, Sandström EG, Knapp JS, et al. Epidemiology of penicillinase-producing Neisseria gonorrhoeae infections: analysis by auxotyping and serotyping. $N$ Engl $J$ Med 1982;306:950-4.

9 Kohl PK, Knapp JS, Hofmann H, et al. Epidemiological analysis of Neisseria gonorrhoeae in the Federal Republic of Germany by auxotyping and serological classification using monoclonal antibodies. Genitourin Med 1986;62:145-50. 